\title{
ON THE OCCURRENCE OF OTOZAMITES IN AUSTRALIA, WITH DESCRIPTIONS OF SPECIMENS FROM WESTERN AUSTRALIA.
}

\author{
By A. B. Walkom, D.Sc.
}

(Flate x.)

Last year a collection of fossil plants from near Mingenew, W.A., was made available to me for examination through the kindness of Dr. W. G. Woolnough. Almost all the specimens in the collection represent species of Otozamites, a genus of rather limited occurrence in Australia, and this opportunity is taken, while describing these species, of gathering together the few records of the scattered occurrence of the genus in this Continent.

Among the Western Australian collection there are no new species, bat some of the specimens are different from those previously described from Australia.

The only description of specimens of Otozamites from Western Australia is that by Arber (1910) who deseribed O. Feistmanteli Zigno from about three miles south of Mingenew, at an altitude of about 500 feet above the town. He ealled attention to the possibility of identity between the Western Australian fronds and specimens from the Lower Oolite of Germany figured by Kurr as O. Mandelslohi; and also pointed out that examples figured under the same name by Salfeld (1907, Pl. xvi., figs. $1 a, 1 b, 1 c$ ) from the Lias of Wurtemburg do not appear to be identical with the Australian fronds.

The specimen from the Talgai Coalfield, Queensland, which Feistmantel (1890, p. 147, Pl. 28, fig. 9, 9a) had referred to O. Mandelslohi is, as Arber suggested (1910, p. 26), identical with some of the Western Australian examples, and should be referred to $O$. Feistmanteli Zigno. The original of Feistmantel's figure is in the collection of the Geological Survey of New South Wales, and, through the courtesy of Mr. W. S. Dun, Palaeontologist, I have been able to examine it.

In addition to Otozamites Feistmanteli, Arber also recorded the oceurrence of indeterminable fossil wood fragments, of coniferous fragments, and of small seed-like bodies from the same locality. He suggested that the coniferous fragments might be compared with such forms as Pagiophyllum Kurri Schimper, Araucaria (Pagiophyllum) peregrina Kurr or the fragment figured by Tenison-Woods (1883, p. 165, pl. 4, fig. 1) as Cunninghamites australis.

In drawing up a table of fossil plants recorded from Western Australia, L. Glauert, unfortunately enters all three of these species $(1910$, p. 110) so that this single indeterminate fragment is represented in his table by three separate entries. 
The specimens described in the present communication were obtained by Dr. Woolnough and Mr. J. L. Somerville, B.Sc., from a spot about three miles north of Mingenew Railway Station and at a height of about 125 feet above the station which is 502 feet above sea level. The collection is largely due to the enthusiasm of Mr. G. Wells, a local resident, through whom the specimens were obtained. They were found in a ferruginous sandstone lying almost horizontally and little is known about the stratigraphical relations. There are at least 70 feet of sandstone below the plant-bearing bed. In association with these sandstones there are marine beds of Jurassic Age, but there is doubt as to whether the marine beds are below or above the plant-bearing sandstones.

For the available information regarding the field occurrence I am indebted to Dr. Woolnough and Mr. Somerville, and I would express my thanks especially to Dr. Woolnough for the opportunity of examining the collection.

Three species of Otozamites have been recognised, viz.:-O. Bechei, $O$. Feistmanteli and $O$. bengalensis. In addition there are also coniferous fragments (? Pagiophyllum sp. and ? Elatocladus sp.), a doubtful cone, and indeterminate fragments of fossil wood.

Otozamites Bechei Brongniart. (Fl. x., figs. 3, 4).

1825 Filicites Bechii, Brongniart, Ann. Sei. Nat., iv., Pl. xix., fig. 4 1834 Otopteris obtusa, Lindley and Hutton, The Fossil Flora of Great Britain, Pl. exxviii.-1849 Otozamites obtusus, Brongniart, Tableau, p. 104.-1900 Otozamites obtusus, var. ooliticus, Seward, The Jurassic Flora (Cat. Brit. Mus.), p. 218, Pl. i., fig. 1; Pl. ii., fig. 2.-1917 Otozamites obtusus, Walkom, Q'land. Geol. Surv., Pub. 259, p. 21, Pl. 8, fig. 1.

This specific name is used broadly to include numerous Cycadean fronds which have generally been deseribed as Otozamites obtusus, which name, as Seward $(1917$, p. 540$)$ has pointed out, must give way to $O$. Bechei.

"Frond pinnate; pinnae usually more or less falcate, oceasionally straight and with parallel sides, attached obliquely to the upper side of the rachis; imbricate or separate, the upper edge of the base of the lamina strongly auriculate, the lower edge rounded; apex obtuse; veins strongly divergent especially in the lobed base and extending obliquely to the upper and lower edge of the lamina."

The specimens under examination agree well with the description and figures of this species. The fronds are about $4.5 \mathrm{~cm}$. wide, with pinnae $2.5 \mathrm{~cm}$. long and $7-8 \mathrm{~mm}$. wide. The pinnae in general make an angle of $65-70^{\circ}$ with the rachis. The fronds are elongate lanceolate and would appear to be at least $20 \mathrm{~cm}$. in length. The veins are divergent and numerous; there are about 12 at the base of the pinna, while further out, after they divide, there are about 15 in a breadth of $5 \mathrm{~mm}$.

The same species has been described from Beaudesert, in Queensland (Walkom, 1917, p. 21).

$$
\text { Otozamites Feistmanteli Zigno. (Pl. x., fig. 7). }
$$

1881 Otozamites Feistmantel, Zigno, Flora Foss, Oolit., Vol. 2, p. 90, t. 34, f. 6-8.-1883 Otozamites Mandeslohi, Tenison-Woods, Proc. Linn. Soc. N.S.W., viii., p. 151.-1890 otozamites Mandelslohi, Feistmantel, Mem. Geol. Surv. N.S.W., Fal. 3, p. 147, t. 28, f. 9, 9a.-1892 Otozamites Mandelslohi, Etheridge Jr., Geol. Fal. Q'land., p. 381.-1910 Otozamites Feistmanteli, Arber, Geol. Surv. W.A., Bull. 36, p. 25.-1917 Otozamites Feistmanteli, Walkom, Q'land. Geol. Surv., Pub. 259, p. 23, t. 8, f. 2, 3. 
"Frond narrow, linear; pinnae short and broad, attached to the upper face of the rachis by a broad base, of which the upper corner is slightly auriculate; the apex is bluntly rounded, the tip being directed upwards. Venation of the Otozamites type." (Seward, 1900, p. 221).

The fronds in the Western Australian specimens are about $3 \mathrm{~cm}$. wide, but as all are incomplete it is not possible to determine the length. The pinnae are up to $1.7 \mathrm{~cm}$. long and $7-8 \mathrm{~mm}$. wide, with a rounded end. Their upper margins have a broad lobe near the rachis, the lower margins being straight. There are about 3 veins per $\mathrm{mm}$.

The specimen from Talgai, Queensland, referred by Feistmantel (1890, p. 147) to O. Mandelslohi (Kurr) should be placed in this species.

This species is smaller and narrower than $O$. Bechei. Apart from the size and general shape there is not a great deal of difference between the fronds referred to these two species. But they are fairly distinct and, though numerous specimens are available, there is an absence of examples intermediate between the two.

Otozamites Bengalensis Oldham and Morris. (Plate x., figs. 1, 2, 6).

1863 Palaeozamia Bengalensis, Oldham and Morris, Mem. Geol. Surv. Ind. (Pal. Ind.), Ser. ii., Vol. 1, Pt. 1, p. 27, Pl. xix., figs. 1, 2, 6.

This species was originally described and figured by Oldham and Morris from the lowest beds of the Rajmahal Group in India.

The frond is long and narrow, with short, relatively broad pinnae. In the Western Australian specimens the narrow linear fronds are up to about $1.8 \mathrm{~cm}$. wide, but their length is indeterminate; one specimen, $9 \mathrm{~cm}$. in length, is $1.8 \mathrm{~cm}$. wide at its upper end and only narrows to $1.6 \mathrm{~cm}$. wide at its lower end. The pinnae are up to $1 \mathrm{~cm}$. in length and 5 or $6 \mathrm{~mm}$. in width; they are obtusely rounded, but nearer the base of the frond become somewhat more acute. From above, the rachis is practically hidden. The veins are divergent and branch dichotomously; at the base of the pinna there are usually $6-10$ veins, and further out they are more numerous, there being 4 to 5 per $\mathrm{mm}$. The upper margin of the pinna has an obtuse lobe near the base; the lower margin is not lobed and is overlapped to about half its length by the upper margin of the next lower pinna.

Comparison of the specimens with the original figures of Oldham and Morris leaves little doubt of their identity. The species has not previously been described or recorded from Australia, but I have seen specimens from near Durikai, some thirty miles south-west from Warwick, Q., which I believe are identical.

It is possible that the specimens deseribed as $O$. ef. Mandelslohi Kurr. from the Darling Downs, near Toowoomba, Q., (Walkom, 1917, p. 23), may belong to this species, though they differ somewhat in general appearance, having rather broader, more orbicular pinnae.

The specimens described above are from a locality some miles distant from that in which the specimens deseribed by Arber (1910) were obtained. It is not possible to tell from Arber's published notes whether any specimens with the dimensions of $O$. bengalensis were amongst the collection submitted to him. It does not seem likely, however, that he would have included specimens with such narrow, elongate, linear form with $O$. Feistmanteli.

Loc.-About 3 miles north of Mingenew, W.A. 


\section{? Elatoclades sp.}

A small fragment on specimen F12473 shows the basal portions of a number of pinnae attached to a rachis; the pinnae are about $2 \mathrm{~mm}$. wide at the base and have a well-defined midrib in the portion visible. The specimen may be tentatively referred to Elatocladus.

\section{? CONE.}

A fragment, about $2 \mathrm{~cm}$. long, of what may have been a cone, shows a number of spherical bodies, each about $3 \mathrm{~mm}$. in diameter, attached to an axis. There are five of these bodies on each side of the axis, but it is impossible to give any details of their strueture or of their arrangement on the axis. The specimen is F12473 in the Geological Survey Collection.

\section{Coniferous fragments. (Pl. x., fig. 5).}

Associated with the Otozamites there are obseure fragments of what appear to be coniferous branches. They show no detail of structure; the outline of one is figured, but no attempt is made to attach a definite name to them. Possibly they are what Arber $(1910$, p. 27$)$ compared with Pagiophyllum sp.

There are also some fragments of fossil wood, but they apparently have no traces of structure preserved and it is impossible to make any use of them.

\section{The Occurrence of Otozamites in Australia.}

The genus Otozamites attains its widest geographical distribution in rocks of Jurassic age, but also oceurs fairly abundantly in both Triassic and Lower Cretaceous Formations. In Australia, up to the present, it has only been found in rocks of Jurassic age and its geographic range in this region appears to have been limited. Rocks of Jurassic age are known in all the States and also in New Zealand, but so far, Otozamites has been recorded only from Queensland and Western Australia. Since, however, the Jurassic rocks in northern New South Wales (Clarence Series) are directly connected with those of southern Queensland in which this fossil occurs, future collecting may be expected to reveal the occurrence of Otozamites in New South Wales.

In the Jurassie Rocks of Victoria, Tasmania, and New Zealand, which are considerably further south than those already referred to, Otozamites does not appear to be present. It may be that the climatic eonditions were not suitable for the growth of this plant, since there does not appear to have been any other formidable barrier to prevent it spreading to the south. But just as the Cycads of to-day do not extend into Vietoria or Tasmania, so may those of Mesozoic times have been restricted to a like extent.

In Queensland, species of Otozamites have been found at widely-seattered localities in the south-east, viz.:-Thane's Creek and Durikai (both to the south-west of Warwick), Talgai, Darling Downs near Toowoomba, Kalbar (formerly Engelsburg), Beaudesert, and near Esk. At all of these localities, with the exception of Esk, the species are of similar general characters to those found in Western Australia, the records being: O. Bechei from Beaudesert, O. Feistmanteli from Thane's Creek, Talgai and Kalbar, O. ef. Mandelslohi from Darling Downs near Toowoomba, and $O$. bengalensis from Durikai.

The specimens described from Esk (Walkom, 1917, p. 21) are quite distinct from any of the above and some doubt has been expressed as to whether 
they are rightly referred to the genus. Dr. Stopes (1918, p. 230) differs from my determination of them as Otozamites, but does not suggest to what genus she considers they should be referred.

The rocks in which these species occur are all referred to the Walloon Series or its equivalents, which are of undoubted Jurassic age.

The Western Australian occurrences of Otozamites are confined, so far as is known, to the neighbourhood of Mingenew, and Madinganarra, to the north of Derby. The only published records are those of Arber (1910), about three miles south of Mingenew, and A. Gibb Maitland (1919, p. 41) near Derby, in addition to those described in the present paper from about three miles north of Mingenew. The species comprise $O$. Bechei, $O$. Feistmanteli and $O$. bengalensis from the neighbourhood of Mingenew, and $O$. sp. from Madinganarra.

Mr. A. Gibb Maitland, in his Summary of the Geology of Western Australia (1919, p. 41), records the occurrence of the genus in the north-west of Australia thus :-

"Dr. H. Basedow obtained in 1916 several impressions of Mesozoic ferns in a yellowish argillaceous sandstone or grit met with in a well at Madinganarra, near Point Torment, to the north of Derby in King Sound in the Kimberley Division. The specimens have been determined by the late Mr. R. Etheridge, Jun., as Otozamites, together with stem impressions of either Phyllotheca, Equisetites, or Schizoneura. The evidence of these plant remains would seem to indicate a Jurassic age for the beds and a horizon equivalent to that of the beds in the vicinity of Mingenew."

Further confirmation of the presence of Jurassic rocks in the neighbourhood of Derby is afforded by the occurrence of fossil plants which have been deseribed by Antevs (1913). These include Thinnfeldia Feistmanteli from Mayils Well, near Derby, oceurring in a light gray clay at a depth of 300 feet, and Ptilophyllum ? sp. from Point Torment, 32 miles from Derby, in a soft, coarse, reddish sandstone at a depth of 30 feet.

The examination of the specimens, described above, from Mingenew shows a very remarkable lithological similarity between the Jurassic sandstones in which the fossils oceur in Western Australia and Queensland. This is a darkred, ferruginous sandstone and, if collections from the two States were mixed, it would indeed be difficult to separate the Queensland from the Western Australian specimens. There is also an indication of the occurrence of a similar type of rock containing Ptilophyllum in the Derby district in Antevs' deseription of fossil plants from that area, quoted above.

Attention has previously been called to the widespread development of this rock in Queensland and to the probability of it indicating a well-marked horizon in the Walloon Series (Walkom, 1918, p. 50). Possibly it is the result of some special climatic conditions and it gives indication of the synchronous deposition of the strata over a comparatively wide area. It should certainly prove a very valuable horizon when more detailed stratigraphical work is done on the Jurassic strata of Australia.

In writing on the subject of Geologic Climates, F. H. Knowlton refers to the subject of Red Beds (1919, p. 506) and his remarks may be quoted here as having some bearing on the indications afforded by this widespread development of a red sandstone in regard to the climatic conditions of the period during which it was deposited. He says:- "At this point I may stop for a moment to consider the deductions to be drawn from the presence of red beds. Most geologists interpret the presence of red beds as an indication of aridity. 
On the contrary, it seems to me that the evidence is fairly conclusive that red beds may have been formed under conditions of warm, moist climates. Briefly, the reasons for this view are as follows: (1) So far as known, red beds are not being formed at the present time in any desert region, but as maturely weathered residual soils they are being formed in southern temperate and tropical regions, and in warm, moist climates. (2) The plants found in red beds, as, for example, in the Permian, Triassic, etcetera, are not pinched or depauperate, nor do they exhibit marked xerophytic adaptations. Moreover, very considerable deposits of coal are found in red beds in many parts of the world, which implies the presence of swamps but little above sea level."

It is not argued here that the Australian beds under discussion are typical "red beds," but it may be pointed out that the term is somewhat loosely used, and the prevailing colour of these beds might lead to their being quoted as examples of red beds by writers not acquainted with them in the field or by specimens.

These remarks are very much strengthened, in my opinion, when we take into consideration the known flora of this particular sandstone in Australia. Though somewhat seanty, a flora consisting essentially of Osmundites, Taeniopteris and Otozamites, could not be considered to indicate the existence of arid conditions where it flourished.

It may therefore be argued that the very widespread oceurrence of this red sandstone with its persistent and characteristic, though scanty, flora probably indicates a fairly uniform, warm, moist elimate over the northern half of Australia in Jurassic times. What climatic signifieance the absence of Otozamites from the Jurassic Rocks of Southern Australia has is not yet clear, for Taeniopteris oceurs abundantly in Victorian Jurassic rocks, and both Osmundites and Taeniopteris occur in New Zealand.

\section{List of Works referred to.}

Antevs, E., 1913.-Results of Dr. E. Mjöberg's Swedish Scientific Expedition to Australia, 1910-1913. V. Some Mesozoie Plants, $K$. Svensk. Vet. Akad., Handl., lii., No. 5.

Arber, E. A. N., 1910.- Some Fossil Plants from Western Australia. Geol. Survey W.A., Bull. 36, pp. 25-28.

Feistmantel, O., 1890.-The Geological and Palaeontological Relations of the Coal and Flant-bearing beds of Palaeozoic and Mesozoie age in Eastern Australia and Tasmania. Mem. Geol. Surv. N.S.W., Pal. 3.

Glauert, L., 1910.-Western Australian Fossil Plants. Geol. Survey W.A., Bull. 36, pp. $107-110$.

Knowlton, F. H., 1919.-The Evolution of Geologic Climates. Bull. Geol. Soc. Amer., xxx., No. 4, pp. 499-566.

Mattland, A. Gibe., 1919.-A Summary of the Geology of Western Australia. Extract from the Mining Handbook. Geol. Surv. Memoir, No. 1, Chapter 1.

SALFELD, H., 1907.-Fossile Land-pflanzen der Rät- und Juraformation Sudwestdeutschlands. Palaeontographica, liv., p. 182.

Seward, A. C., 1900.-The Jurassic Flora, Pt. i. British Museum Catalogue.

SEward, A. C., 1917.-Fossil Plants. Vol. iii. 
Stopes, M., 1918.-Palaeobotany in 1917. Science Progress, No. 50, Oet., 1918, pp. 225-232.

Tenison-Woods, J. E., 1883.-On the Fossil Flora of the Coal Deposits of Australia. Proe. Linn. Soc. N.S. Wales, viii., p. 37.

Walkom, A. B., 1917.-Mesozoie Floras of Queensland. Part i. (concluded). Q'land. Geol. Survey, Fub. 259.

WaLkom, A. B., 1918.-The Geology of the Lower Mesozoic Rocks of Queensland. Proc. Linn. Soc. N.S. Wales, xliii., 1918, pp. 37-115.

\section{EXPLANATION OF PLATE $\mathrm{X}$.}

The specimens figured on this plate have been presented to the Geological Survey of New South Wales, their registered numbers being 12469-12472 inclusive.

1. Otozamites bengalensis Oldham and Morris. View of upper surface of frond. (F12469). Nat. size.

2. Otozamites bengalensis Oldham and Morris. Pinna enlarged ( $\mathrm{x} 3$ ) showing venation.

3. Otozamites Bechei Brongniart. View of upper surface of frond. (F 12470). Nat size.

4. Otozamites Bechei Brongniart. Pinna enlarged (x2) showing venation.

5. Coniferous branch (? Pagiophyllum sp.) (F 12471). Nat. size.

6. Otozamites bengalensis Oldham and Morris. View of impression of lower surface of frond, with the rachis removed. (F 12472). Nat size.

7. Otozamites Feistmanteli Zigno. Drawing of portion of frond. (F 12471). Nat. size. 


\section{$2 \mathrm{BHL}$ Biodiversity Heritage Library}

Walkom, A.

B.

. 1921. "On the occurrence of Otozamites in Australia, with descriptions of specimens from Western Australia." Proceedings of the Linnean Society of New South Wales 46, 147-153. https://doi.org/10.5962/bhl.part.14005.

View This Item Online: https://www.biodiversitylibrary.org/item/23930

DOI: https://doi.org/10.5962/bhl.part.14005

Permalink: https://www.biodiversitylibrary.org/partpdf/14005

\section{Holding Institution}

MBLWHOI Library

\section{Sponsored by}

MBLWHOI Library

\section{Copyright \& Reuse}

Copyright Status: NOT_IN_COPYRIGHT

This document was created from content at the Biodiversity Heritage Library, the world's largest open access digital library for biodiversity literature and archives. Visit BHL at https://www.biodiversitylibrary.org. 